\title{
The fragility in the land of refugees: Jordan and irrepressible phenomenon of refugee camps
}

\section{Hind Alshoubaki}

Department of Architecture and Urban Planning,

D'Annunzio University of Chieti-Pescara,

Italy

bind.alshoubaki@unich.it

\section{Lucio Zazzara}

Department of Architecture and Urban Planning,

D'Annunzio University of Chieti-Pescara,

Italy

Lucio.zarzara@unich.it

Abstract. Refugee camps are complex systems in which very light structures are transforming into permanent cities with very deteriorated urban qualities, services, and infrastructures, producing a fragile environment. However, no previous study has assessed the fragility in refugee camps, often because of the lack of appropriate quantitative indicators to be adopted. Consequently, in this paper, we aimed to fill this gap by developing a fragility index for refugee camps by determining a set of quantitative indicators that could be applied to any refugee camp in the world. The proposed indicators are linked to track four types of fragility: sociopolitical, economic, educational, and health system fragility in refugee camps. In this study, we tracked the risks in 15 refugee camps in Jordan that accommodate Palestinian and Syrian refugees. We developed the schematic diagram for the fragility factors based on the analytical thinking approach and comparative analysis within the United Nations humanitarian organization camp planning standards and the descriptive analysis for the fragility indicators dataset. Therefore, classifying the fragility of refugee camps based on these risks creates a concrete means for planners to determine the most critical risks, to diminish their impacts, and to attain resilience.

Keywords: fragility, refugee camp, resilience, risk

JEL Classification: R23, R58 


\section{INTRODUCTION}

Forced displacement, especially in protracted crisis, has greatly promoted unavoidable negative risks, which significantly affect humans' well-being and a city's urban structure. The arising conflicts worldwide increased not only the number of refugees but the number and size of refugee camps (United Nations High Commissioner for Refugees [UNHCR], 2018). Jordan is a case in point of how refugee camps stand for decades and are being transformed into fragile cities. Jordan is strategically located in the heart of the Arab world, and since its independence in 1946, it has undergone various waves of displacement (Alshoubaki \& Harris, 2018) since the Arab-Israeli War in 1948, followed by the Six-Day War of 1967 and the Palestinian Intifada in 1987. Recently, in 2012, Jordan received a large exodus of Syrian refugees because of the Syrian Civil War (The Center for Middle Eastern Strategic Studies [ORSAM], 2014). Accordingly, Jordan has around 15 refugee camps ranging from 6 years old up to 70 years. The purpose of this study was to define the fragility in those refugee camps based on four main factors: sociopolitical, economic, education, and health system.

Refugee camps are generally developed in "Autoschediasm" mode, suddenly, unexpectedly, and at the spur of the moment to provide refugees with basic needs quickly and for a short period. They are predominantly constructed based on different manuals and guidelines that have been developed by humanitarian organizations, such as the Handbook for Emergencies (UNHCR, 2007); Refugee Camp Planning and Construction Handbook (2000); and The Sphere Handbook: Humanitarian Charter and Minimum Standards in Disaster Response (2004). The technical standards for the camp planning focus on the temporary character as a main feature during the first phase of the emergency. Subsequently, the temporary mind-set creates serious problems and transforms those temporary structures into ramshackle cities, putting the displaced persons among the most vulnerable populations. They face severe risks as a result of the poor living conditions inside the camps, which increases their fragility because fragility is an accumulation of risks. However, no guide or study helps to understand the risks and vulnerabilities in those spaces after their prolonged existence.

At the same time, there is a notable increase in the body of literature that discusses the challenge of providing a good quality of life for huge numbers of people congesting in our cities today (The Royal Institution of Chartered Surveyors [RICS], 2018). Comfort, well-being, and quality of life concepts are considered powerful objectives in different contexts such as justice, economy, or the environment (Fracolli et al, 2011), as well urban planning and design. The adoption of indicators of material, social, and psychological needs satisfaction has become a significant tool in assessing quality of life and identifying and evaluating comfort and well-being characteristics (Mishchuk \& Grishnova, 2015). Quality of life is considered a critical aspect in sustaining any urban environment (Serag El-Din et al., 2012), and the planner's aim is to upgrade comfort and well-being in every setting and for all inhabitants (Lotfi \& Solaimani, 2009). The quality of life in cities cannot be enhanced by depending only on brick and mortar; it requires human satisfaction with different urban and social attributes such as population and building densities, service availability, accessibility of basic goods, quality of public spaces, protecting public health, and providing safety, security, and education (Serag El-Din et al., 2012).

Various urban researchers have addressed quality of life issues within an urban setting. McCrea et al. (2005) discussed the urban quality of life in Australia at different geographical levels: regional, neighborhood, and housing levels. The researchers found that regional satisfaction was best predicted by the cost of living and the availability of services such as health and education. Neighborhood satisfaction, however, was best predicted by social interaction, crime rates, and public facilities. Additionally, housing satisfaction was best predicted by age of home and homeownership. Richards et al. (2006) discussed the quality of life of informal settlements in three clusters in South Africa by investigating the main factors that could improve their quality of life. The researchers concluded that material living standards, housing, and basic services; social 
connectivity; and personal health care are the major contributing factors in improving life quality. Mishchuk and Grishnova (2015) conducted a comparative assessment of comfort and well-being in Ukraine and some European countries. The researchers found that health care needs and conditions for life extension and protection of human rights were the most significant external migration factors. Serag El-Din et al. (2012) broke down the notion of urban quality into three narrower terms: quality, quality of life, and urban/urban planning. The researchers found that urban quality could be categorized based on seven dimensions: environmental, physical, mobility, social, psychological, economic, and political. The City Resilience Index (CRI, 2016) was an attempt to assess the resilience of cities, using both qualitative and quantitative assessment to evaluate the strengths and weaknesses of cities. The report involved 52 indicators that shape the qualities that impact cities' resilience. The report concluded that a city's resilience relates to four key dimensions: people, organizations, places, and knowledge.

Refugees' and migrants' comfort, well-being, and quality of life have been extensively examined in different fields such as political science, health care, education, built environment, and international development. The aim of this study was to look at refugee camps with an urban logic — considering them emerging urban environments with a population equivalent to regular cities (De Rooij, Wascher, \& Paulissen, 2016) and with social, political, environmental, and economic problems just like any unplanned metropolitan area-to understand their failure in providing comfort, well-being, and good quality of life. Thus, we conducted this study to shed light on the main perils that shape fragility in 15 refugee camps in Jordan and to propose an index and a schematic diagram for their fragility, which could be applied to different cases of such informal settlements in the world.

\section{LITERATURE REVIEW}

Refugee camps are transformed from momentary cities into long-lasting fragile cities, they are urbanized as much as the cities do. Even though they were built to be temporary but over time they create long-term problems, their presence poses several types of risks while they are growing and turning into cities. The following review of fragility is based on the analytic scheme for studying the refugee camps' fragility which has been categorized into socio-political fragility, economic fragility, educational fragility and health system fragility, in an aim to know how to determine refugee camps fragility to attain resilience.

\subsection{What is fragility?}

Fragile in the urban dictionary has been defined as "it can be easily broken and so it has to be handled with care" (urban dictionary, 2018) and fragility is a measure of how fragile something is. Recently the concept of fragility addressed different debates on states and cities level. African Development Bank, HighLevel Panel on Fragile States (2014) defined fragility as a "risk inherent in the development process itself" that comes about "when [pressures] become too great for national institutions and political processes to manage." Asian Development Bank, "Fragility Index for a Differentiated Approach" (2014) defined Fragility as "a state's failure to perform its function effectively and to provide basic social services, such as health, education, security; incapacity to uphold the rule of law; and failure to provide sustainable sources of income for the population to get out of poverty." UK Department for International Development, "Global Issues: Fragile States" (2010) has defined the fragile states as "those where the government cannot or will not deliver core functions to the majority of its people, including the poor. The most important functions of the state for poverty reduction are territorial control, safety, and security, capacity to manage public resources, delivery of basic services, and the ability to protect and support how the poorest people sustain themselves." 


\subsection{What are the key factors leading to fragility?}

The condition of fragility has been combined with the cities' core capacities so what just defines a fragile city of a non-fragile city is on their capacity to deliver to their inhabitants its services within its core capacities (Muggah, 2016). As stated by Misra (2016) "fragility intensifies where risks and stresses accumulate, undermine services and expose citizens to chronic and acute vulnerability". Fragility is the city dysfunction which shows the weakness of the city in providing primary services to meet inhabitants' basic needs (Bertocchi \& Guerzoni, 2011).

\subsubsection{Sociopolitical fragility}

One of the most critical macro-level factors which play a key role in hastening city fragility is the rapid and unregulated urbanization (Muggah, 2014). More than half of the worlds' population currently live in cities in comparison to 1950 where a third of the world was urban community and by 2050 we will have 6 billion lived in cities (UN Habitat, 2017). In the same vein, it is remarkable that also the refugee camps are urbanizing as a result of the great acceleration in the number of uprooted people (Zazzara \& Alshoubaki, 2018). Consequently, the number of official refugee camps and the unofficial refugee camps like Idomeni in Greece and the Calais in France (Smith, 2016) have been increased. Where 17.8 million are living in refugee camps and by 2030 the slum population will reach two billion (UNHCR, 2018).

Refugee camps all around the world host hundreds of thousands of refugees as declared by UNHCR (2012) the average-sized camp housed around 11400 persons. The mere fact that refugee camps are urbanizing based on the population density since the population density inside refugee camps is impacted by different factors: the first one is the natural growth, which depends on the birth and death rates and they indicate high birth rates, for example in Zaatari refugee camp in Jordan an average of 80 births weekly and in Al-Azraq camp an average of 35 children are born monthly in hospitals (UNHCR, 2018). The United Nations Population Fund 'UNFPA's humanitarian coordinator proclaims that the crude birth (CBR) (which defined as the number of live births per 1000 people per year) in Al-Azraq camp is 40, compared to 24.5 in Jordan. Whilst the mortalities in Zaatari has been reported to the first half of 2018 was 105 person and for Al-Azraq was 10 mortalities among the ten, three were prenatal (UNHCR, 2018). The second is the continuous decampment of those who are seeking safety far from disastrous events. For example, Zaatari camp was officially opened in July 2012 to accommodate around 30,000 Syrian refugees, the camp has received 1500 refugees every night who crossed the borders seeking safety (UNHCR, 2012). The refugee camps in Jordan are showing incredible densities where they reveal on ratios higher than the highest cities densities such as Monaco with 25,709.4 inhabitants per square $\mathrm{km}$ and Macao with 20,098.4 inhabitants per square $\mathrm{Km}$ (Duffin, 2019). The growing numbers of refugees inside the camps consistently put their livability at the gunpoint or as (De Rooij, Wascher \& Paulissen, 2016) addressed it as a quasi-urbanization process. 


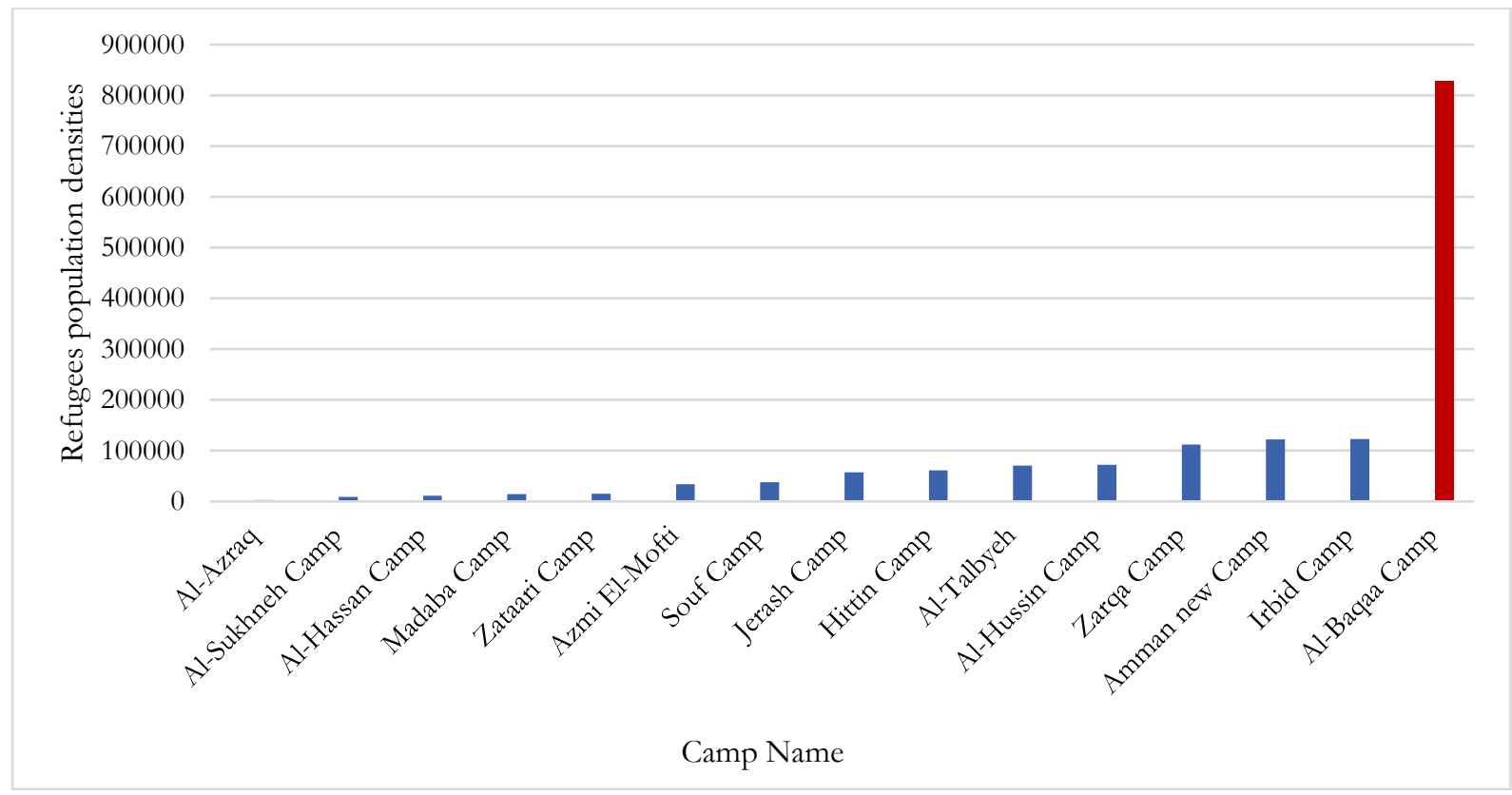

Figure 1. The population densities in Jordan's refugee camps Source: UNHCR \& UNRWA 2018; Authors' calculations

\subsubsection{Economic fragility}

Economic fragility could be defined as a basis to the market's outcome and the unemployed rates, even there is limited evidence that unemployment leads to fragility but the common literature goes toward that job-creation is a sustainable process in fragile states toward resilience (Hinds, 2015). Shedding the light to refugees' communities, different deep debates discussed their economic presence as a burden or a benefit (Alshoubaki \& Harris, 2018). But economically speaking, the refugees' presence in refugees' camps is likely to be positive. From a perspective of urban planning, economic growth and urbanization are strictly connected (Turok \& McGranhan, 2013). Refugees have variously shaped different economic activities to maintain their dignity and normalcy (Oka, 2014) seeking to be independent just on international assistance. Although the camps' economies are highly affected by the host counties' policies (Wecker, 2007) but the refugees are aware enough to their need for a private business. For instance, the Kakuma refugee camp in Kenya has a highly vibrant economy where refugee owned and operated shops and restaurants to serve not only the refugees inside the camp but also the host community. In a prove of that when UNHCR, decided to close Kakuma in the 2000s because of the South Sudan agreement, the host community rejected this action as they consider the camp as the main source of employment, business opportunities and commercial goods (Saughi, 2015) where the interaction is not only economic but social and cultural including marriages between the refugees and/or with the host communities. As a result of their protracted existence refugees construct livelihoods and contribute to economies around (Betts, 2013). The case is clear in Jordan's refugee camps where the number of markets in refugee camps is very high for example over an area of $5.3 \mathrm{Km}^{2}$ in Zaatari camp there are around 3000 markets (UNHCR, 2018). 


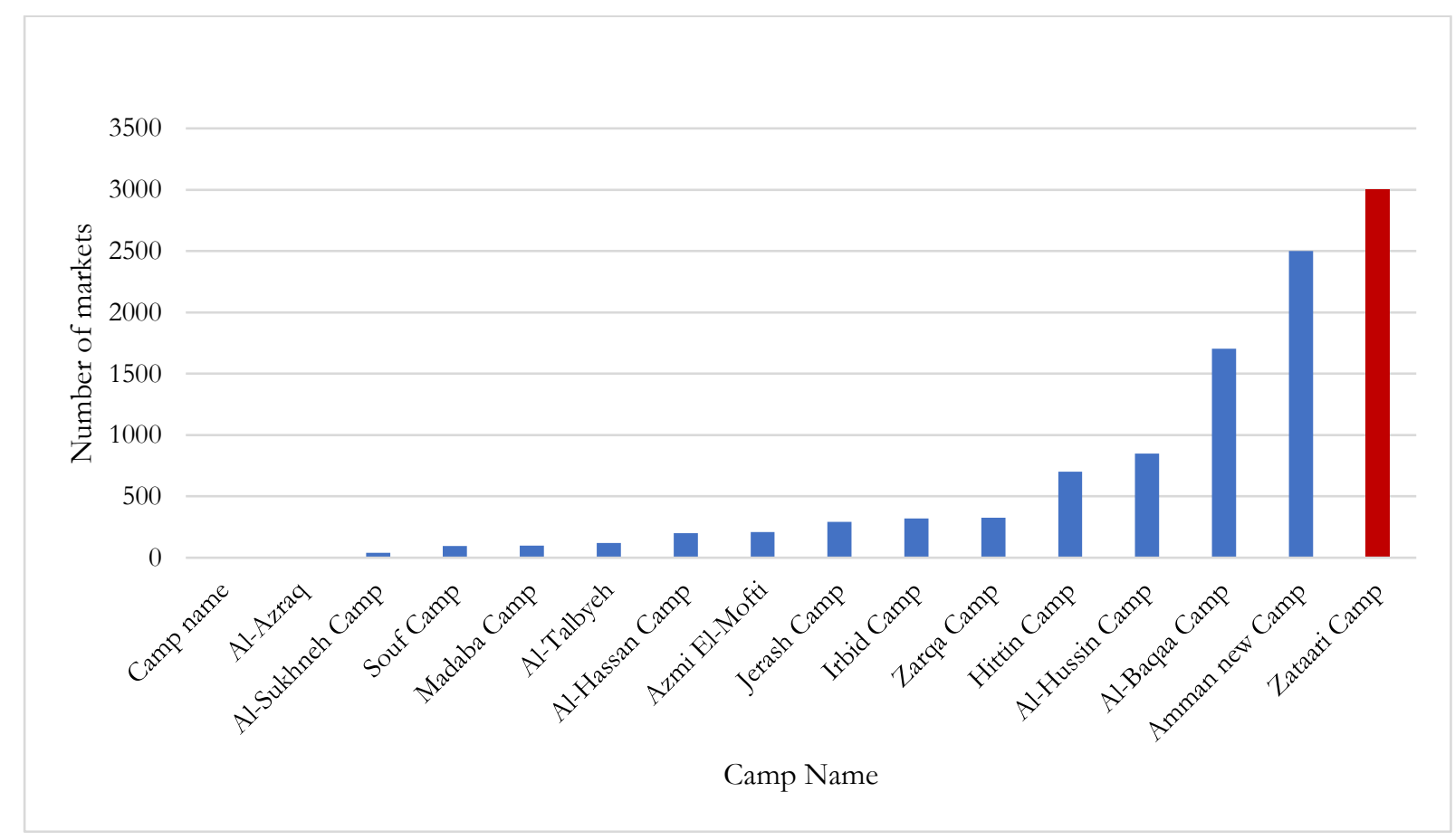

Figure 2. The number of markets in Jordan's refugee camps Source: UNHCR \& UNRWA 2018

\subsubsection{Education and health system fragility}

Fragility and resilience are not on the opposite side of the spectrum hence, providing basic services is considered as a benchmark of an effective urban development to achieve resilience. In this regard, this factor could be measured based on the status of education and health services (The United Nations University [UNU], 2016). Although many refugee camps failed to meet refugees' needs as they have not taken into consideration their prolonged existence where refugees spent around an average of 17 years in exile (UNHCR, 2017). Most of them transformed into permanent cities within a short time such as the Kilis refugee camp in Turkey with no sufficient clinics, schools or grocery stores (Rawles, 2016). Based on the World Health Organization [WHO] (2019), refugees and migrants generally have good health statue but they become vulnerable to sickness while transitioning and because of the poor living conditions, lack of health services or conversions in their lifestyle. The humanitarian organizations were conscious of the importance of education in refugee camps as an important tool to help communities to emerge by providing them with sufficient spaces in which students learn to peacefully live and work together (Inter-Agency Network for Education in Emergency [INEE], 2018). This is appearing in the refugee camps in Jordan whether the Palestinians or Syrians camps where the number of schools is extremely sufficient and even the Jordanian citizens enrolled in the United Nations Relief and Works Agency for Palestine Refugees [UNRWA] schools for the Palestinian refugees (UNRWA, 2018). 


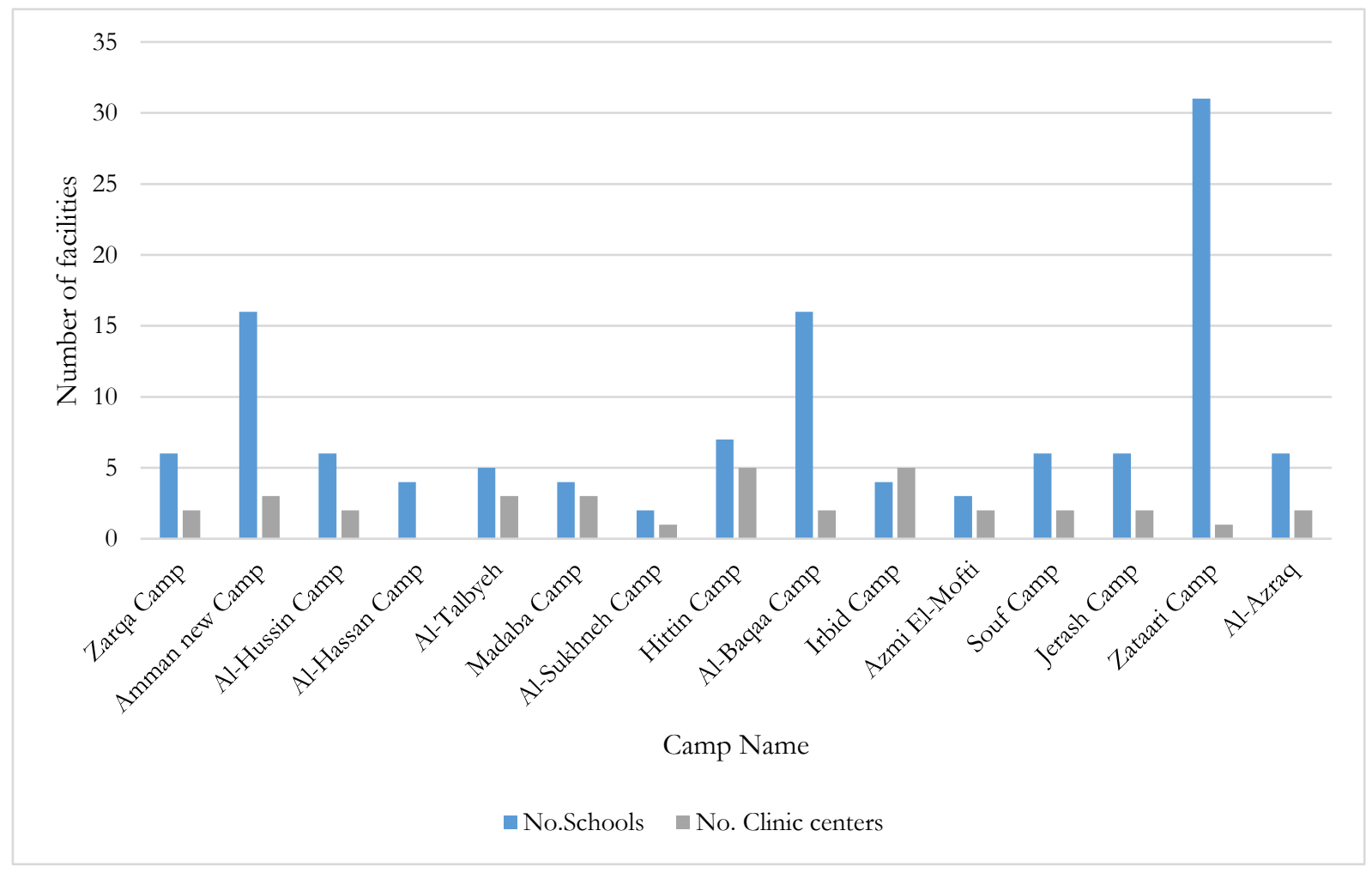

Figure 3. The number of schools and health facilities in Jordan's refugee camps Source: UNHCR \& UNRWA 2018

A run through the literature, there is a lack of specific theory to determine the fragility in refugee camps which leads the researcher to reflect the fragility measures in states and cities into camps while putting in evidence the camps transformation into functioning cities, because fragility is a consequence of an accumulation of risks, as mentioned before, and regarding to literature the city's core capacities are the main factor in determining if the city is fragile or not and since refugee camps are transforming into cities, this study will predict in any core capacities the risk lies aiming to protect and improve these core capacities to attain resilience, hinging on UNHCR (2018) as stated in "An approach to emergencies" (OXFORD, 1997) the main core capacities that usually do exist in any refugee camp are the following: sleeping accommodations whether tents or caravans, clinics, hospitals, immunization centers, security units, schools, training centers, and places of worship.

This assessment is based on the available statistical data for the Syrian refugee camps from UNHCR and that for the Palestinians refugee camps from UNRWA. The retrieved data from both of the organization was as the following: the camp area $\left(\mathrm{m}^{2}\right)$, the population density, the number of families in one residential unit, the area of the residential unit $\left(\mathrm{m}^{2}\right)$, the camp population/unit, the numbers of security centers, the number of schools, the number of markets and the number of clinics.

The genuineness of this research in addressing the fragility in refugee camps requires to follow logical analytical approach to determine the main risks and challenges that face the refugee community in Jordan and to classify them within four main types of fragility combined with the camp core capacities and since indicators become significant tool in determining and evaluating the quality of life (Fracolli et al., 2011) and they are a good instrument to breakdown a big picture into small pieces ( The Monitoring and Evaluation Reference Group [MERG], 2010). The focus of this study is on the services outcome in refugees' settlements rather than their access to them. Consequently, the indicators of this assessment have been 
constructed to acquire a new policy depending on the obtained data from UNHCR and UNRWA database system and as discussed by MERG (2010) that the reliability and the validity of the indicators are identified by the quality of the collected data, they must be very context-specific and reflect the local circumstances. Considering that indicators are essential components in monitoring and evaluating a specific phenomenon, these components are metadata that check the underlying viability of each indicator. The indicators add further definition for the refugee camps risks and identify the main critical factors of fragility that contribute in building resilient refugee camp and they also integrate the indicators of state vulnerability in the fragile state index and they are: cohesion, economic, political and social (Fragile State Index [FSI], 2007) with evidence from the literature of comfort, QoL, and resilience in cities.

This study tracks the risks in 15 refugee camps in Jordan regarding 9 variables which have been determined based on the academic literature and linked with fragility indicators. The study analyzes each camp (11) variables to determine if it is fragile or not, depending on the camp planning standards of the emergency handbook, so at the end of this analysis we will be able to determine the main critical risks, in an aim to know from where one should start the journey of resilience in refugee camps spaces. Appertaining on that deliberation, the aim of this research is to answer the following two research questions:

1. What kind of fragility does exist in each refugee camp in Jordan: Sociopolitical fragility, economic fragility, educational fragility or health system fragility?

- Sociopolitical fragility which has been linked with the following indicators: the camp area $\left(\mathrm{m}^{2}\right)$, the population density, the number of families in one residential unit, the number of security centers, the number of residents in one unit, the area of residential unit $\left(\mathrm{m}^{2}\right)$.

- Economic fragility which has been linked with the number of markets

- Educational fragility which has been linked with the number of schools

- Health system fragility which has been linked with the number of clinics

2. What are the most impacted core capacities which make the camp fragile?

\section{METHODOLOGY}

The refugee camps index in this paper has been developed based on analytical thinking approach that allows us to breakdown such a complex problem step by step logically and rationally to tackle the new idea regarding the fragility of refugee camps. The analysis of refugee camps fragility was developed based on the following steps:

After determining the main factors and their indicators that drive fragility in refugee camps based on the cities fragility index while putting in evidence the transformation of refugee camps into cities by analyzing and synthesizing the content of different articles, reports and Gray literature. The researchers checked the status of each refugee camp in Jordan - of the 15 refugee camps- if it is fragile or resilient by calculating each camp indicators based on United Nation humanitarian organization camp planning standards and compare its current conditions with what it is supposed to be. UN humanitarian organizations create guidance notes which define the minimum standards required to ensure planned settlements to help refugee communities to live with security and dignity in a healthy environment which improves their quality of life (UNHCR, 2018).

The sociopolitical fragility has been determined by six main indicators. Thus, the calculations were as the following: Firstly, the recommended camp settlement size $=$ the camp population $/ 45 \mathrm{~m}^{2}$. Secondly, UNHCR recommends an area of $45 \mathrm{~m}^{2}$ per person. Consequently, the accepted population density according to UNHCR standards has been calculated and it equals 0.022 . So, the refugee camp population density should meet this value. Thirdly, the recommended covered living area has been calculated based on 
UNHCR refugee camp standards as follows: the number of unit's inhabitants $/ 3.5 \mathrm{~m}^{2}$. Fourthly, every residential unit should accommodate one family of 4-6 members. Consequently, the refugee camp residential units should meet this range. Finally, UNHCR declared that the number of security's centers depends on the circumstance but one at least must exist. See appendix 1.

Table 1

Minimum standards of refugee camp planning

\begin{tabular}{|l|l|}
\hline Description & Minimum standard \\
\hline Covered living area & $3.5 \mathrm{~m}^{2}$ per person \\
\hline Camp settlement size & $45 \mathrm{~m}^{2}$ per person \\
\hline School & 1 per 5000 persons \\
\hline Health center & 1 per 20,000 persons \\
\hline Market place & 1 per 20,000 \\
\hline Security & Dependes on the circumstance \\
\hline Residents/unit & $4-6$ persons per one residential unit \\
\hline Family/unit & 1 family per one residential unit \\
\hline
\end{tabular}

Source: UNHCR Emergency Handbook, 2018

The economic fragility has been linked with the number of markets and market places. Accordingly, the number of recommended markets could be calculated as follows: the camp population/20,000. See appendix 2. To check the educational fragility depending on UNHCR refugee camps planning standard, the number of schools should exist is any refugee camp could be calculated based on the following equation: No.of recommended schools $=$ the camp population/5000. See appendix 3. Then, the Health system fragility has been predicted by the number of clinics, therefore and based on UNHCR refugee camp planning standards, the number of health facilities could be calculated as follows: No. of recommended health facilities = the camp population/20,000. See appendix 4. Then, in order to determine what kind of fragility does exist in each camp, the researchers used the descriptive analysis for the current conditions inside each refugee camp and then they compare the ratio of every type of fragility in each camp to get an image of the kind of risks in an aim to attain resilience.

\section{RESULTS AND DISCUSSION}

The data analysis for the fragility indicators showed that $86.6 \%$ of the refugee camps in Jordan are showing fragility based on the number of people who live in one residential unit. $73 \%$ of the camps are fragile because of the camp area and 66.6 of the camps are fragile due to population density. The results assured that fragility is a dynamic property where one could find most of the camps show fragility in some indicators but they were resilient in others. But in the same vein, it is cumulative while fragility hits more indicators the camp will reveal a noticeable fragility. The overall analysis leads us to determine what kind of fragility does each camp suffers from whether: sociopolitical fragility, economic fragility, educational fragility or health system fragility. 


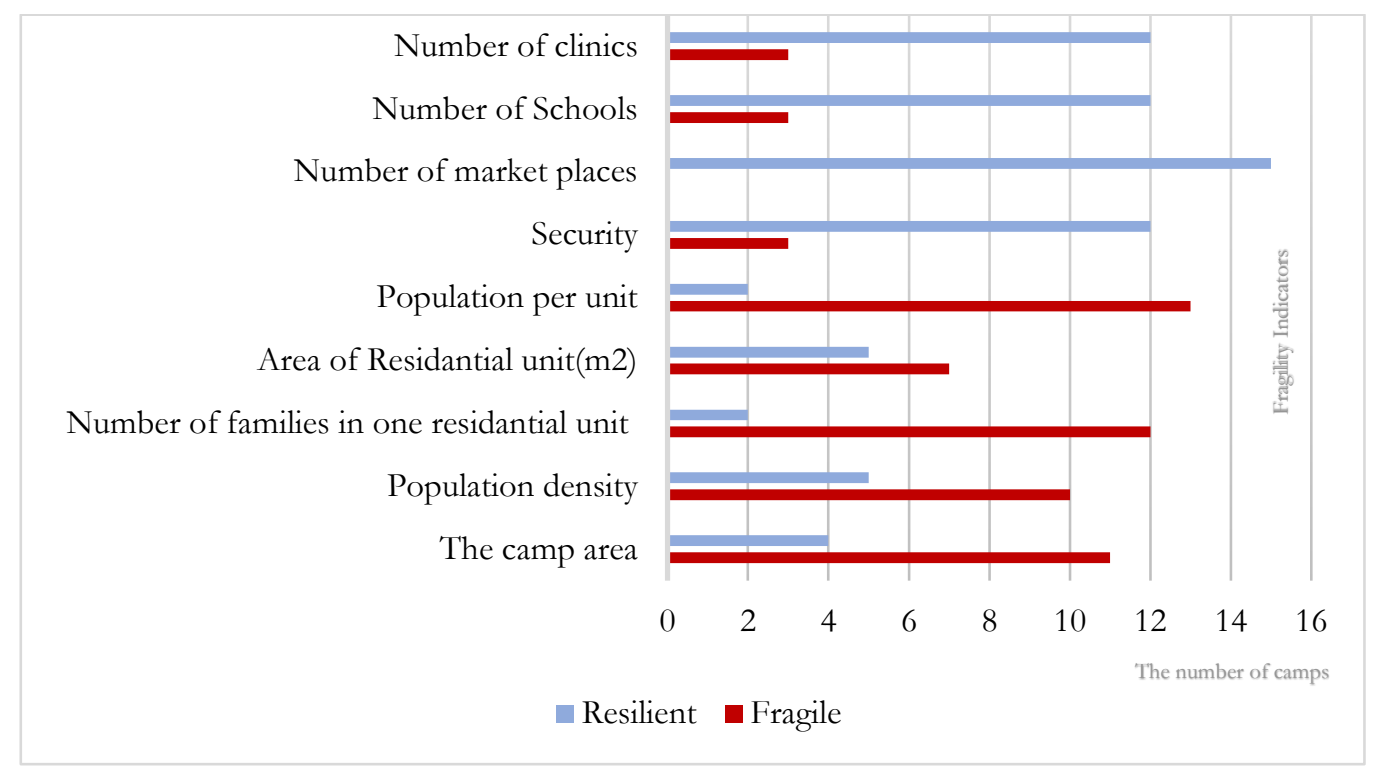

Figure 4. The fragility index of the refugee camps in Jordan

Source: The authors' results

The sociopolitical fragility in Jordan's refugee camps: the analysis showed that $73.3 \%$ of the refugee camps in Jordan are suffering from sociopolitical fragility, which is highly motivated firstly: by the camp settlement area (m2), as could be seen in figure 5, Al-Baqa'a camp shows high levels of sociopolitical fragility. Secondly: the number of populations living in the same residential unit. For instance, an average of 27 persons lives in one residential unit within $100 \mathrm{~m} 2$ in Amman's new camp. The population densities inside the camps shape a great risk in which the area of the camps is not extendable but the numbers of refugees are remarkably increasing. The results showed that all the refugee camps in Jordan are economically resilient, as could be noticed in figure 6 , where refugees develop their own business inside the camps, as could be seen in figure 6, that Al-Sukhnah camp and Al-Azraq camp are less resilient than the other camps in Jordan but they are not in the economic fragility zone. The educational fragility analysis showed that $33.3 \%$ of Jordan's refugee camps survived educational fragility, as could be seen in figure 7, Al-Baqa'a camp and Hittin camp show the highest level of educational fragility in comparison to other camps. The results showed that $20 \%$ of Jordan's refugee camps experienced fragility in their health system, as shown in figure 8 , that AlBaqa'a camp, the Za'atari, and Al-Hassan camp are with the highest level of health-system fragility. 


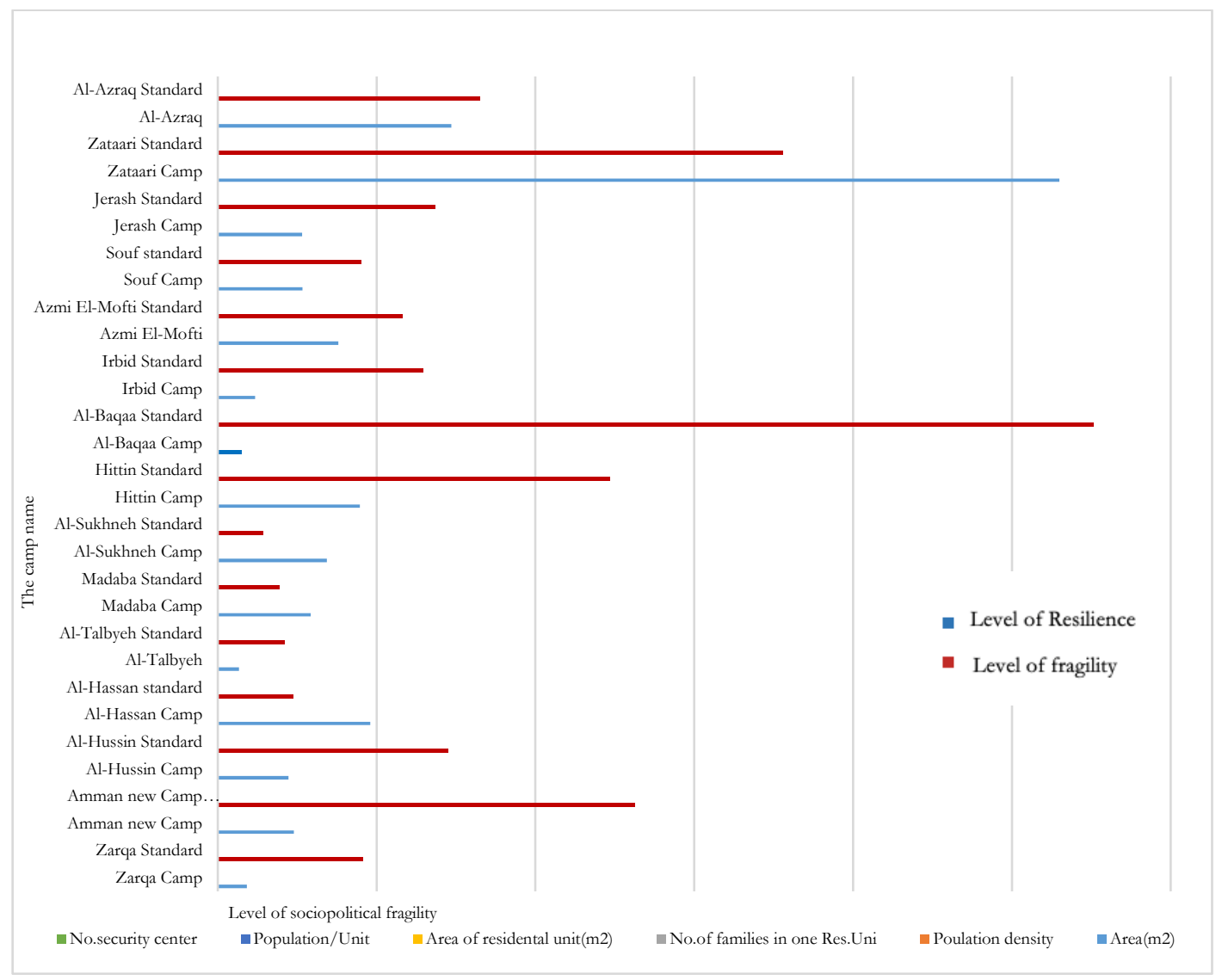

Figure 5. The sociopolitical fragility

Source: Authors' results

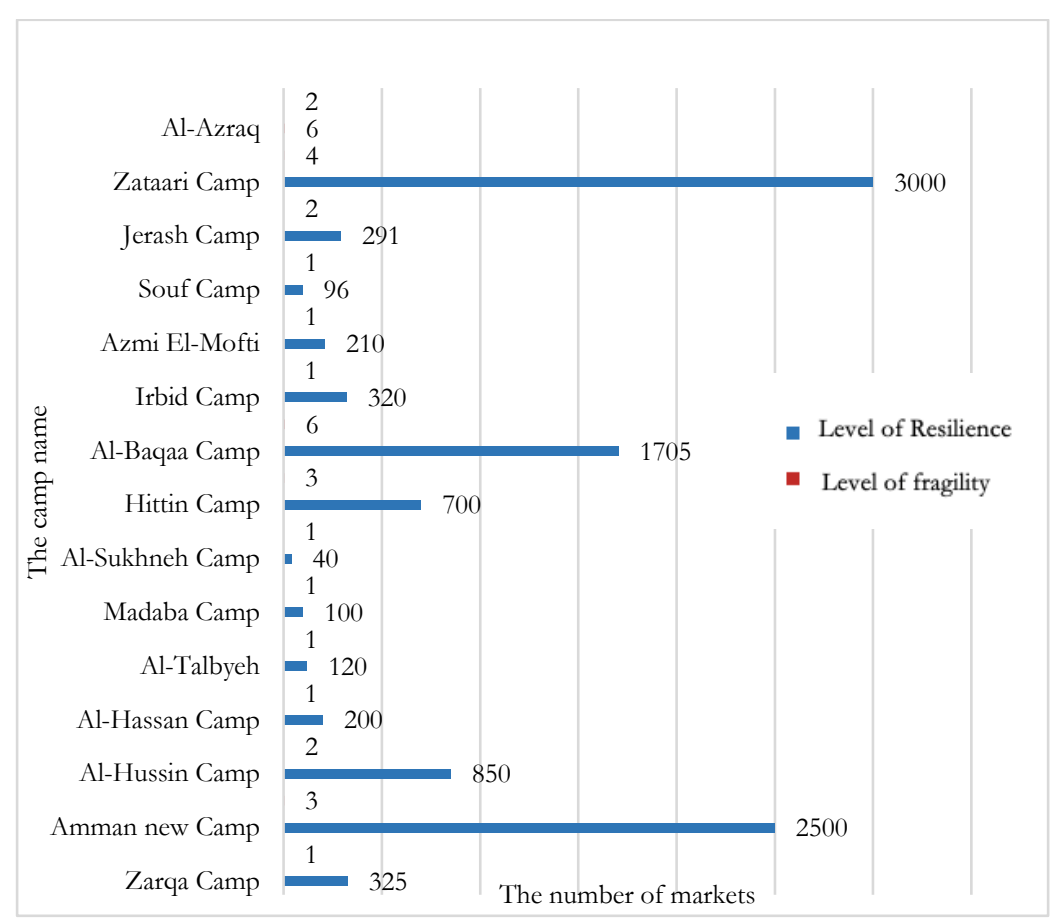

Figure 6. The economic fragility Source: Authors' results 


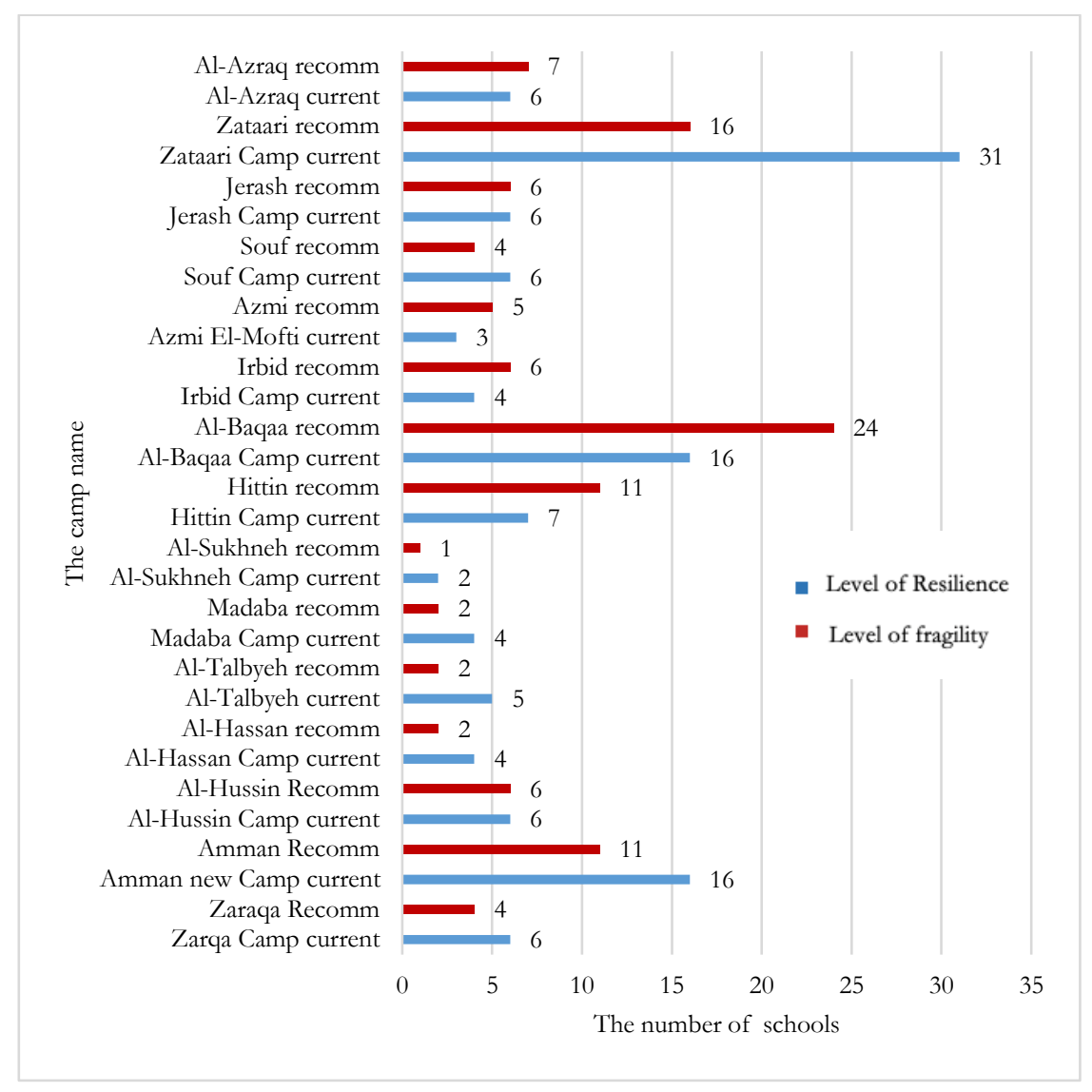

Figure 7. The educational fragility Source: Authors' results

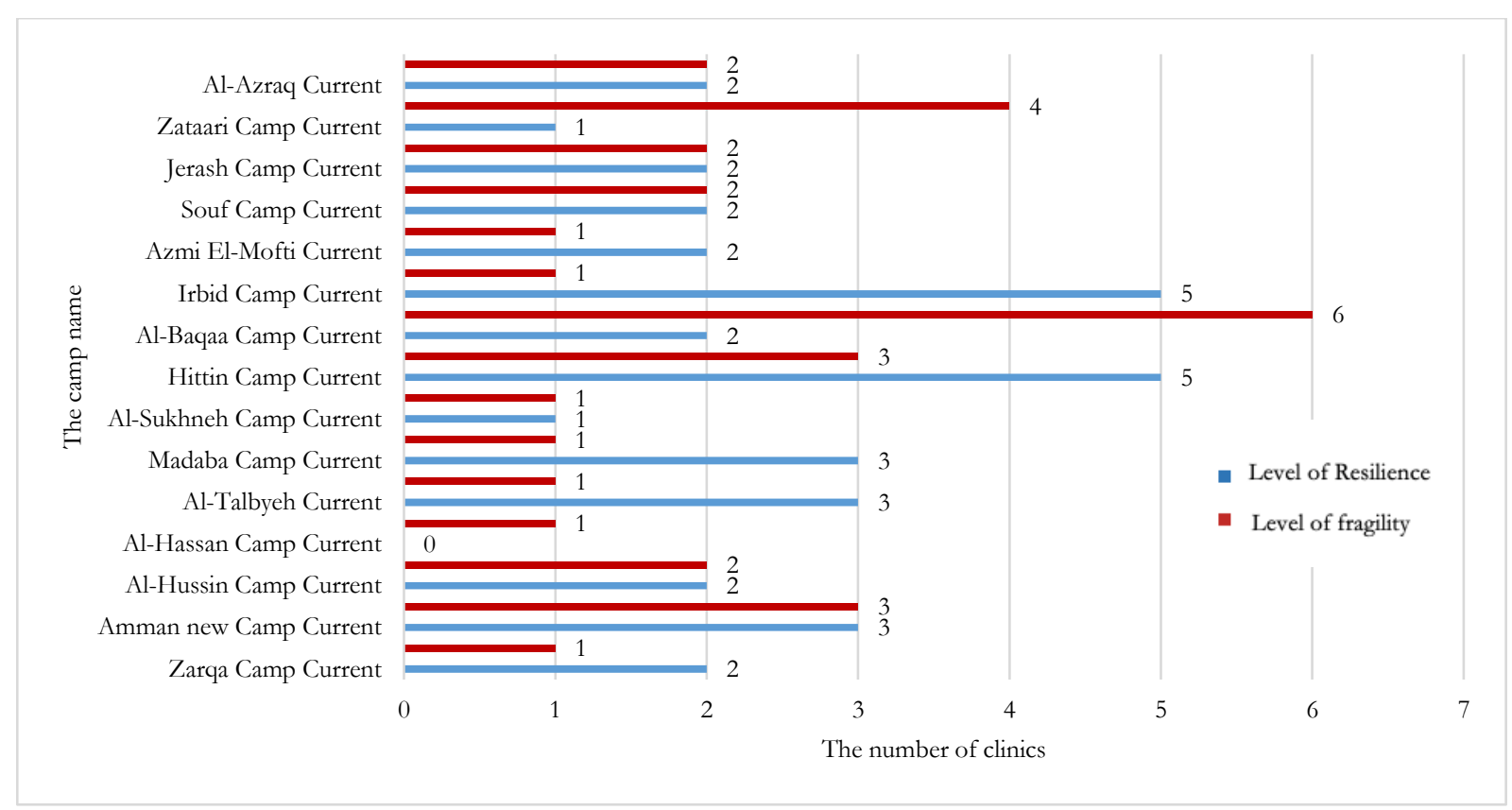

Figure 8. The health-system fragility

Source: Authors' results 
The final phase of the data analysis has determined the type of fragility in each refugee camp in Jordan by comparing the level of fragility exposed in each camp. The figure below shows the chronological sequence for all the refugee camps in Jordan which have been instituted since 1949 up to the last camp for the Syrian refugees in 2014 and it describes what type of fragility each camp suffers from. This sketch is stemmed from the data analysis for the fragility factors and indicators as shown previously and it could be a reference point to protect the camps' core capacities to guide them toward resilience. Since the systematic explanation for this urban phenomenon suggests a schematic explanation of what happened inside those types of settlements.

Testing the current conditions of refugee camps based on the planning standards which have been outlined by humanitarian organizations prove that this type of normative planning is suitable to the first stage of emergency where refugees are looking for safety and security far from conflicts or even natural risk but it does not take in consideration their prolonged existence where even if the area of the camp was restricted but the society living there is not, as they are growing in age and numbers and consequently, they will naturally move from physiological and safety needs to attain self-actualization in the refugee society.

It is quite important to shift the policies of refugee camps planning the need for a planned refugee camp is as bigger as the camp itself. As Elizabeth Cullen (2015) in her essay the "failure of refugee camps" asked for creating "Real Cities", she stated that: camps keep refugees alive but they prevent them from living. When a refugee's environment is lacking the public spaces in quality and quantity because of the type of standardized, frozen planning make the idea of such open spaces impossible to apply. Accordingly, the refugees will inevitably move and seek new places in case they were permitted to leave. But one could imagine when fragility in camps born? The refugees themselves arrived fragile and broken, they left their homes under bombs and their journey toward safety is harrowing and riskiness. Once they "Reborn" as Hamid, one of the Syrian refugees in Zaatari called it "Once we crossed those areas where there was fighting, we felt like we were reborn," (Beals, 2013). By time, the unknown relationship between refugees and the new land starting to appear because refugee camps are born without an idea to the society living there, their identity, their need, desires or aspiration, and that shape the fragility of these spaces which has the destiny to grow in time because of their long time of existence which produce growing numbers of citizen, a very great number which is impossible to cope with current urban quality. Where very high densities with insufficient services and infrastructure. The story begins from people in conflict ending to spaces in crisis.

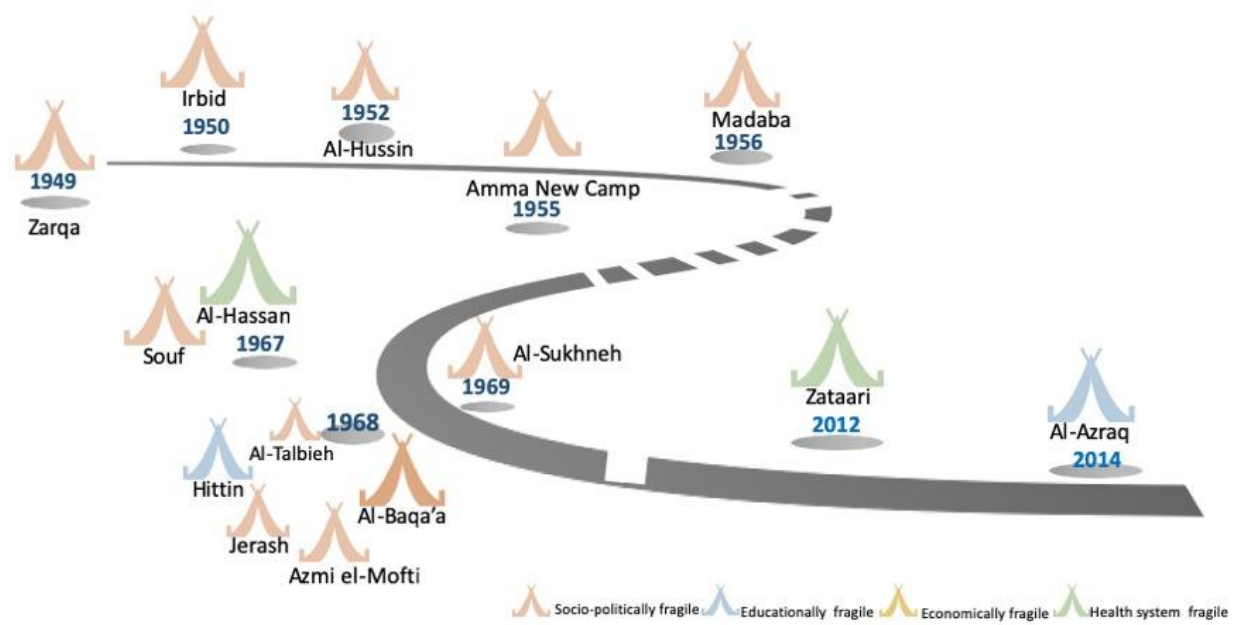

Figure 9. The type of fragility appears in every refugee camp in Jordan

Source: The authors' results 


\section{CONCLUSION}

In conclusion, since the concept of fragile refugee camp unfolds from the notion of the fragile city, the schematic diagram and the fragility factor analysis has been implemented to track the risks inside the refugee camps to grab their overall performance. The absence of discussing and dealing with the refugee camps as an urban phenomenon leads to aggravating the risks in such settlements, the analysis illustrates the fragility in refugee camps could be: sociopolitical, economic, educational or in their health system. The schematic diagram showed what kind of fragility does exist in each refugee camp in Jordan to know where we are and how to react, which provides a platform to protect the specific core capacities in each camp to attain resilience. This study is a step in an important direction towards refugee camps as an urban phenomenon and not only to re-think in planning policies in designing refugee camps as pre-planned cities but redeveloping new measures to reduce all types of risks could be in refugee camps.

Planning the refugee camps implicate certain uncertainties, as no one knows when the refugees will return but everyone recognizes that refugee camps, especially in case of conflict, are lasting for decades, as being noticed the refugee camps in Jordan even the most recent one is considered as "protracted", Protracted refugee situation as defined by UNHCR: "one in which refugees find themselves in a long-lasting and intractable state of limbo. Their lives may not be at risk, but their basic rights and essential economic, social and psychological needs remain unfulfilled after years in exile. A refugee in this situation is unable to break free from enforced reliance on external assistance" (UNHCR, 2014). UNHCR defines protracted refugee populations as: "on in which 25,000 or more refugees of the same nationality have been in exile for 5 years or longer in any give asylum country" (UNHCR, 2004). Refugee camps neither temporary nor tented structures, they are permanent cities, consequently, an urgent need to shift the focus on just sheltering during the emergency phase where most of the refugee camps are stuck in. This raises the alarm to update and upgrade the camp planning standards to meet their fact of existence as cities since the tents could be replaced with harder materials, then with constructing small and multi-story unites but once they take the city shape it is impossible to change them as the study proved that the fragility in Jordan's refugee camps is highly noticed as a result of population densities over a very deteriorated urban quality. The analysis of fragility factors appertaining to the UN standards showed the need for improving these standards, as they are helpful in the state of emergency but they are lacking in the time factor which plays an essential role in forming those spaces into cities. Furthermore, the absence of a comprehensive vision in which one must take into consideration a suitable plan and infrastructure for those with special needs who cannot even have a life out of the camp border or the children who grow in these spaces or elderly who are fragile. It is quite important to introduce new policies regarding the importance of open public spaces and specific types of services. In such exceptional phenomena of cities, all the policies must be stemmed from human activities, because being in limbo does not mean being margined and forgotten.

\section{REFERENCES}

Alshoubaki, W., \& Harris, M. (2018). The impact of Syrian refugees on Jordan: A framework for analysis. Journal of International Studies, 11(2), 154-179. doi:10.14254/2071-8330.2018/11-2/11

Bertocchi, G., \& Guerzoni, A. (2012). Growth, history, or institutions: What explains state fragility in sub-Saharan Africa?. Journal of Peace Research, 49(6), 769-783.

Bett, L.J., (2013). The effect of diaspora remittances on economic growth in Kenya. University of Nairobi.

De Rooij, B., Wascher, D., \& Paulissen, M. (n.d.). Sustainable design principles for refugee camps. Netherlands: Wageningen University and research.

Duffin, E. (2019, July 1). Population by race in the U.S. 2000-2018. Retrieved from https://www.statista.com/statistics/183489/population-of-the-us-by-ethnicity-since-2000/ 
Fracolli, L. A., Zoboli, E. L. P., Granja, G. F., \& Ermel, R. C. (2011). The concept and practice of comprehensiveness in Primary Health Care: nurses' perception. Rev Esc Enferm USP, 45(5), 1135-41.

Fragile definition. (2006). Retrieved 2018, from https://www.urbandictionary.com/define.php?term=fragile

Fragile state index FSI. (2007). The Fund for Peace. Retrieved from https://fragilestatesindex.org/

Serag El Din, H., Shalaby, A., Farouh, H. E., \& Elariane, S. A. (2013). Principles of urban quality of life for a neighborhood. Hbrc Journal, 9(1), 86-92. doi: 10.1016/j.hbrcj.2013.02.007

Hinds, R. (2015, April). Economic growth and fragility. Retrieved from http://gsdrc.org/publications/economicgrowth-and-fragility/

INEE. (2018). Education in Emergencies. Retrieved from https://archive.ineesite.org/en/education-in-emergencies

Mccrea, R., Stimson, R., \& Western, J. (2005). Testing a moderated model of satisfaction with urban living using data for Brisbane-South East Queensland, Australia. Social Indicators Research, 72(2), 121-152. https://doi.org/10.1007/s11205-004-2211-x

Médecins, S. F. (1997). Refugee health: an approach to emergency situations. Macmillan Education Ltd..

Mishchuk, H., \& Grishnova, O. (2015). Empirical study of the comfort of living and working environment - Ukraine and Europe: comparative assessment. Journal of International Studies, 8(1), 67-80. doi: 10.14254/2071$8330.2015 / 8-1 / 6$

Misra, T. (2016, September 26). How Fragile Is Your City? Retrieved from https://www.citylab.com/equity/2016/09/where-the-fragile-cities-are/501233/

Muggah, R. (2014). Deconstructing the fragile city: Exploring insecurity, violence and resilience. Environment and Urbanization, 26(2), 345-358. doi:10.1177/0956247814533627

Muggah, R., Patel, R., \& De Boer, J. (2016, October 19). Conceptualizing city fragility and resilience. Retrieved from https://cpr.unu.edu/conceptualizing-city-fragility-and-resilience.html

Oka, R. C. (2014). Coping with the refugee wait: The role of consumption, normalcy, and dignity in refugee lives at Kakuma Refugee Camp, Kenya. American Anthropologist, 116(1), 23-37. doi: 10.1111/aman.12076

ORSAM (2014). Effects of the Syrian refugees in Turkey. ORSAM report No 195 (Ankara: ORSAM). https://www.orsam.org.tr/

Pineo, H., \& Rydin, Y. (2018). Cities, health and well-being. The Royal Institution of Chartered Surveyors (RICS), 1-40.

Rawles, J. (2016). Developing Social Work Professional Judgment Skills: Enhancing Learning in Practice by Researching Learning in Practice. Journal of Teaching in Social Work, 36(1), 102-122. doi:10.1080/08841233.2016.1124004

Richards, R., O’Leary, B., \& Mutsonziwa, K. (2007). Measuring quality of life in informal settlements in South Africa. Social Indicators Research, 81(2), 375-388. doi: 10.1007/s11205-006-9014-1

Lotfi, S., \& Solaimani, K. (2009). An assessment of urban quality of life by using analytic hierarchy process approach (case study: comparative study of quality of life in the North of Iran). Journal of Social Sciences, 5(2), 123-133.

Sanghi, A. (2015, March 15). The peculiar economics of a refugee camp: "Yes in my backyard". Retrieved from https://www.brookings.edu/blog/future-development/2015/03/25/the-peculiar-economics-of-a-refugeecamp-yes-in-my-backyard/

Smith, S., Lane, G., \& Fidler, M. (2015, August 10). Migrant life in Calais' Jungle refugee camp - a photo essay. Retrieved from https://www.theguardian.com/media/ng-interactive/2015/aug/10/migrant-life-in-calais-junglerefugee-camp-a-photo-essay

The United Nations High Commissioner for Refugees UNHCR. (1982). Handbook for emergencies. Geneva.

The United Nations Relief and Works Agency for Palestine Refugees in the Near East

Turok, I., \& Mcgranahan, G. (2013). Urbanization and economic growth: The arguments and evidence for Africa and Asia. Environment and Urbanization, 25(2), 465-482. doi:10.1177/0956247813490908

UN Habitat. (2012). Resilience. Retrieved 2018, from https://unhabitat.org/resilience/

UNHCR. (2018, June). Operational Data Portal. Retrieved 2018, from https://data2.unhcr.org/es/documents/details/64114

United Nations. (2018, June 19). Figures at a Glance. Retrieved from http://www.unhcr.org/figures-at-a-glance.html UNRWA. (2018). Jordan. Retrieved from https://www.unrwa.org/where-we-work/jordan 
WHO. (2019, January). 10 things to know about the health of refugees and migrants. Retrieved February 2020, from https://www.who.int/news-room/feature-stories/detail/10-things-to-know-about-the-health-of-refugeesand-migrants

Werker, E. (2007). Refugee camp economies. Journal of Refugee Studies, 20(3), 461-480. doi: 10.1093/jrs/fem001

Zazzara, L., \& Alshoubaki, H. (2018). Reconstructing Cities in Peacetime: Urban Issues in Post-War Scenarios. Pescara: Carsa edizioni. 


\section{APPENDICES}

\section{APPENDIX 1}

\begin{tabular}{|c|c|c|c|c|c|c|c|}
\hline \multicolumn{8}{|c|}{ Sociopolitical Fragility } \\
\hline & $\begin{array}{c}\text { Camp } \\
\text { area }\left(\mathrm{m}^{2}\right)\end{array}$ & $\begin{array}{c}\text { Population } \\
\text { density }\end{array}$ & $\begin{array}{l}\text { No.of families in } \\
\text { one Res.Un }\end{array}$ & $\begin{array}{c}\text { Area of } \\
\text { residential } \\
\text { unit }\left(\mathrm{m}^{2}\right)\end{array}$ & $\begin{array}{l}\text { Populatio } \\
\text { n/Uni }\end{array}$ & $\begin{array}{l}\text { No.securit } \\
\text { y center }\end{array}$ & $\begin{array}{l}\text { Camp } \\
\text { Status }\end{array}$ \\
\hline Zarqa Camp Current & 182000 & 0.11 & 4 & 100 & 18 & 1 & \multirow{4}{*}{ Fragile } \\
\hline Zarqa Recommended & 914220 & 0.02 & 1 & 99 & 4 to 6 & 1 & \\
\hline Zarqa camp status & Fragile & Fragile & Fragile & Resilient & Fragile & resilient & \\
\hline $\begin{array}{l}\text { Amman New Camp } \\
\text { Current }\end{array}$ & 479000 & 0.12 & 6 & 100 & 27 & 1 & \\
\hline $\begin{array}{l}\text { Amman New Camp } \\
\text { Recommended }\end{array}$ & 2623995 & 0.02 & 1 & 148.5 & $4-6$ & 1 & \multirow[t]{2}{*}{ Fragile } \\
\hline $\begin{array}{l}\text { Amman new camp } \\
\text { status }\end{array}$ & Fragile & fragile & fragile & fragile & fragile & resilient & \\
\hline $\begin{array}{l}\text { Al-Hussin Camp } \\
\text { current }\end{array}$ & 445000 & 0.07 & 3 & 100 & 13 & 1 & \multirow{3}{*}{ Fragile } \\
\hline $\begin{array}{l}\text { Al-Hussin camp } \\
\text { Recommended }\end{array}$ & 1449765 & 0.02 & 1 & 71.5 & 4 to 6 & 1 & \\
\hline $\begin{array}{l}\text { Al-Hussin camp } \\
\text { status }\end{array}$ & fragile & fragile & fragile & fragile & fragile & resilient & \\
\hline $\begin{array}{l}\text { Al-Hassan Camp } \\
\text { current }\end{array}$ & 961000 & 0.01 & 3 & 95 & 16 & 0 & \multirow{3}{*}{ Fragile } \\
\hline $\begin{array}{l}\text { Al-Hassan camp } \\
\text { Recommended }\end{array}$ & 472500 & 0.02 & 1 & 88 & 4 to 6 & 1 & \\
\hline $\begin{array}{l}\text { Al-Hassan camp } \\
\text { status }\end{array}$ & fragile & resilient & fragile & fragile & fragile & fragile & \\
\hline $\begin{array}{l}\text { Al-Talbyeh camp } \\
\text { current }\end{array}$ & 133000 & 0.07 & 2 & 46 & 11 & 0 & \multirow{3}{*}{ Fragile } \\
\hline $\begin{array}{l}\text { Al-Talbyeh camp } \\
\text { Recommended }\end{array}$ & 420930 & 0.02 & 1 & 60.5 & 4 to 6 & 1 & \\
\hline Al-Talbyeh status & fragile & fragile & fragile & fragile & fragile & fragile & \\
\hline $\begin{array}{l}\text { Madaba Camp } \\
\text { current }\end{array}$ & 586000 & 0.01 & 2 & 90 & 17 & 1 & \multirow{3}{*}{$\begin{array}{c}\text { Resilie } \\
\mathrm{nt}\end{array}$} \\
\hline $\begin{array}{l}\text { Madaba camp } \\
\text { Recommended }\end{array}$ & 385785 & 0.02 & 1 & 93.5 & 4 to 6 & 1 & \\
\hline Madaba camp status & resilient & resilient & fragile & resilient & fragile & resilient & \\
\hline $\begin{array}{l}\text { Al-Sukhneh Camp } \\
\text { current }\end{array}$ & 687000 & 0.009 & 1 & 100 & 13 & 0 & \multirow{3}{*}{$\begin{array}{l}\text { Resilie } \\
\text { nt }\end{array}$} \\
\hline $\begin{array}{l}\text { Al-Sukhneh } \\
\text { Recommended }\end{array}$ & 283500 & 0.02 & 1 & 71.5 & 4 to 6 & 1 & \\
\hline Al-Sukhneh status & resilient & resilient & resilient & resilient & fragile & fragile & \\
\hline Hittin Camp current & 894000 & 0.06 & 4 & 100 & 19 & 1 & \multirow{3}{*}{ Fragile } \\
\hline $\begin{array}{l}\text { Hittin } \\
\text { Recommended }\end{array}$ & 2469420 & 0.02 & 1 & 104.5 & 4 to 6 & 1 & \\
\hline Hittin status & fragile & fragile & fragile & fragile & fragile & resilient & \\
\hline $\begin{array}{l}\text { Al-Baqaa Camp } \\
\text { current }\end{array}$ & 148000 & 0.82 & 3 & 100 & 14 & 1 & \multirow{3}{*}{ Fragile } \\
\hline $\begin{array}{l}\text { Al-Baqaa } \\
\text { Recommended }\end{array}$ & 5516055 & 0.02 & 1 & 77 & 4 to 6 & 1 & \\
\hline Al-Baqaa status & fragile & fragile & fragile & fragile & fragile & resilient & \\
\hline Irbid Camp current & 234000 & 0.12 & 4 & 64 & 17 & 1 & \multirow[b]{3}{*}{ Fragile } \\
\hline Irbid Recommended & 1291050 & 0.02 & 1 & 93.5 & 4 to 6 & 1 & \\
\hline Irbid camp status & fragile & fragile & fragile & fragile & fragile & resilient & \\
\hline $\begin{array}{l}\text { Azmi El-Mofti } \\
\text { current }\end{array}$ & 758000 & 0.03 & 2 & 100 & 11 & 2 & \multirow{3}{*}{ Fragile } \\
\hline $\begin{array}{l}\text { Azmi El-Mofti } \\
\text { Recommended }\end{array}$ & 1159920 & 0.02 & 1 & 60.5 & 4 to 6 & 1 & \\
\hline Azmi El-Mofti status & fragile & fragile & fragile & resilient & fragile & resilient & \\
\hline
\end{tabular}




\begin{tabular}{|l|c|c|c|c|c|c|}
\hline Souf Camp current & 534000 & 0.03 & 4 & Missing & 17 & 1 \\
\hline $\begin{array}{l}\text { Souf camp } \\
\text { Recommended }\end{array}$ & 904365 & 0.02 & 1 & missing & 4 to 6 & 1 \\
\hline Souf camp status & fragile & fragile & fragile & missing & fragile & resilient \\
\hline Jerash Camp current & 531000 & 0.05 & 3 & Missing & 14 & 1 \\
\hline $\begin{array}{l}\text { Jerash } \\
\text { Recommended }\end{array}$ & 1367055 & 0.02 & 1 & Missing & 4 to 6 & 1 \\
\hline Jerash camp status & fragile & fragile & fragile & missing & fragile & resilient \\
\hline Zataari Camp current & 5300000 & 0.01 & 1 & 22.5 & 3 & 6 \\
\hline $\begin{array}{l}\text { Zataari } \\
\text { Recommended }\end{array}$ & 3554730 & 0.02 & 1 & 16.5 & 4 to 6 & 1 \\
\hline Zataari status & resilient & resilient & resilient & resilient & resilient & resilient \\
\hline Al-Azraq current & 1470000 & 0.02 & Missing & 27 & 3 & 5 \\
\hline Al-Azraq Standard & 1651725 & 0.02 & 1 & 16.5 & 4 to 6 & 1 \\
nt \\
nesilie \\
Resilie \\
nt
\end{tabular}

\section{APPENDIX 2}

\begin{tabular}{|c|c|c|}
\hline \multicolumn{3}{|c|}{ Economic fragility } \\
\hline & No.Markets & Camp Status \\
\hline Zarqa Camp current & 325 & Resilient \\
\hline Zarqa Recommended & 1 & \\
\hline Amman new Camp current & 2500 & Resilient \\
\hline Amman Recommended & 3 & \\
\hline Al-Hussin Camp current & 850 & Resilient \\
\hline Al-Hussin Recomm & 2 & \\
\hline Al-Hassan Camp current & 200 & Resilient \\
\hline Al-Hassan Recommend & 1 & \\
\hline Al-Talbyeh current & 120 & Resilient \\
\hline Al-Talbyeh Recommended & 1 & \\
\hline Madaba Camp current & 100 & Resilient \\
\hline Madaba Recomm & 1 & \\
\hline Al-Sukhneh Camp current & 40 & Resilient \\
\hline Al-Sukhneh Recomm & 1 & \\
\hline Hittin Camp current & 700 & Resilient \\
\hline Hittin Recomm & 3 & \\
\hline Al-Baqaa Camp current & 1705 & Resilient \\
\hline Al-Baqaa Recomm & 6 & \\
\hline Irbid Camp current & 320 & Resilient \\
\hline Irbid Recomm & 1 & \\
\hline Azmi El-Mofti current & 210 & Resilient \\
\hline Azmi Recomm & 1 & \\
\hline Souf Camp current & 96 & Resilient \\
\hline Souf Recomm & 1 & \\
\hline Jerash Camp current & 291 & Resilient \\
\hline Jerash Recomm & 2 & \\
\hline Zataari Camp current & 3000 & Resilient \\
\hline Zataari Recomm & 4 & \\
\hline Al-Azraq current & 6 & Resilient \\
\hline Al-azraq Recomm & 2 & \\
\hline
\end{tabular}


APPENDIX 3

\begin{tabular}{|c|c|c|}
\hline \multicolumn{3}{|c|}{ Educational Fragility } \\
\hline Camp name & No.Schools & Camp Status \\
\hline Zarqa Camp current & 6 & Resilient \\
\hline Zaraqa Recommended & 4 & \\
\hline Amman new Camp & 16 & Resilient \\
\hline Amman Recomm & 11 & \\
\hline Al-Hussin Camp & 6 & Resilient \\
\hline Al-Hussin Recomm & 6 & \\
\hline Al-Hassan Camp & 4 & Resilient \\
\hline Al-Hassan recomm & 2 & \\
\hline Al-Talbyeh & 5 & Resilient \\
\hline Al-Talbyeh recomm & 2 & \\
\hline Madaba Camp & 4 & Resilient \\
\hline Madaba recomm & 2 & \\
\hline Al-Sukhneh Camp & 2 & Resilient \\
\hline Al-Sukhneh recomm & 1 & \\
\hline Hittin Camp & 7 & Fragile \\
\hline Hittin recomm & 11 & \\
\hline Al-Baqaa Camp & 16 & Fragile \\
\hline Al-Baqaa recomm & 24 & \\
\hline Irbid Camp & 4 & Fragile \\
\hline Irbid recomm & 6 & \\
\hline Azmi El-Mofti & 3 & Fragile \\
\hline Azmi recomm & 5 & \\
\hline Souf Camp & 6 & Resilient \\
\hline Souf recomm & 4 & \\
\hline Jerash Camp & 6 & Resilient \\
\hline Jerash recomm & 6 & \\
\hline Zataari Camp & 31 & Resilient \\
\hline Zataari recomm & 16 & \\
\hline Al-Azraq & 6 & Fragile \\
\hline Al-Azraq recomm & 7 & \\
\hline
\end{tabular}




\section{APPENDIX 4}

\begin{tabular}{|c|c|c|}
\hline \multicolumn{3}{|l|}{ Health system Fragility } \\
\hline Camp name & No. Clinic centers & Camp Status \\
\hline Zarqa Camp Current & 2 & \multirow[b]{2}{*}{ Resilient } \\
\hline Zarqa Camp Recommended & 1 & \\
\hline Amman new Camp Current & 3 & \multirow[b]{2}{*}{ Resilient } \\
\hline Amman Recommended & 3 & \\
\hline Al-Hussin Camp Current & 2 & \multirow[b]{2}{*}{ Resilient } \\
\hline Al-Hussin Camp Recommended & 2 & \\
\hline Al-Hassan Camp Current & 0 & \multirow[b]{2}{*}{ Fragile } \\
\hline Al-Hassan Camp Recommended & 1 & \\
\hline Al-Talbyeh Current & 3 & \multirow[b]{2}{*}{ Resilient } \\
\hline Al-Talbyeh Recommended & 1 & \\
\hline Madaba Camp Current & 3 & \multirow[b]{2}{*}{ Resilient } \\
\hline Madaba Camp Recommended & 1 & \\
\hline Al-Sukhneh Camp Current & 1 & \multirow[b]{2}{*}{ Resilient } \\
\hline Al-Sukhneh Recommended & 1 & \\
\hline Hittin Camp Current & 5 & \multirow[b]{2}{*}{ Resilient } \\
\hline Hittin Camp Recommended & 3 & \\
\hline Al-Baqaa Camp Current & 2 & \multirow[b]{2}{*}{ Fragile } \\
\hline Al-Baqaa Camp Recommended & 6 & \\
\hline Irbid Camp Current & 5 & \multirow[b]{2}{*}{ Resilient } \\
\hline Irbid Camp Recommended & 1 & \\
\hline Azmi El-Mofti Current & 2 & \multirow[b]{2}{*}{ Resilient } \\
\hline Azmi El-Mofti Recommended & 1 & \\
\hline Souf Camp Current & 2 & \multirow[b]{2}{*}{ Resilient } \\
\hline Souf Camp Recommened & 2 & \\
\hline Jerash Camp Current & 2 & \multirow[b]{2}{*}{ Resilient } \\
\hline Jerash Camp Recommended & 2 & \\
\hline Zataari Camp Current & 1 & \multirow{2}{*}{ Fragile } \\
\hline Zataari Camp Recommended & 4 & \\
\hline Al-Azraq Current & 2 & \multirow[b]{2}{*}{ Resilient } \\
\hline Al-Azraq Recommended & 2 & \\
\hline
\end{tabular}

